\title{
Antimicrobial Behavior of Intracellular Proteins from Two Moderately Halophilic Bacteria: Strain J31 of Terribacillus halophilus and Strain M3- 23 of Virgibacillus marismortui
}

\author{
Badiaa Essghaier*, Cyrine Dhieb, Hanene Rebib, Saida Ayari, Awatef Rezgui Abdellatif Boudabous and Najla Sadfi-Zouaoui
}

Microorganisms and Active Biomolecules Laboratory, Faculty of Sciences of Tunis, University Campus, Tunisia

\begin{abstract}
In the present study, we firstly aimed to determine the ability of halophilic bacteria to improve tomato growth. as well as to detect the antimicrobial activities from two moderately halophilic bacteria strain M3-23 of Virgibacillus marismortui and strain J31 of Terribacillus halophilus exhibited by their intracellular proteins. The results showed that both bacteria were able to improve stem tomato growth by comparison of untreated tomato. The halophilic bacteria were also able to produce intracellular antifungal enzyme: glucanase produced by $V$. marismortui $(1.74 \mathrm{U} / \mathrm{mg})$ and chitinase $(39.39 \mathrm{U} / \mathrm{mg})$ produced by $T$. halophilus. Both chitinases were halotolerants (active in the presence of $(0 \%$ to $30 \% \mathrm{NaCl}(\mathrm{w} / \mathrm{v}))$. Chitinase produced by strain $\mathrm{J} 31$ was alcaline $(\mathrm{pH}$ optimum $\mathrm{pH} 12)$, but chitinase from strain $\mathrm{M} 3$ 23 was acidic ( $\mathrm{pH} 4$ optimum) more than $90 \%$ and $80 \%$ of activities were retained in the presence of $\mathrm{pH}$ value from 4 to 12 , respectively for strain $\mathrm{J} 31$ and M3-23. Both enzymes were thermotolerants; optimum temperature was $80^{\circ} \mathrm{C}$ and $90^{\circ} \mathrm{C}$ respectively for strain $\mathrm{J} 31$ and strain M3-23. Both strains have lysozyme activity and value ranging from 6.6 $\mathrm{U} / \mathrm{ml}$ to $6.8 \mathrm{U} / \mathrm{ml}$ respectively for strain $\mathrm{J} 31$ and strain M3-23. On the whole, the most potent in vitro antifungal effect was demonstrated by intracellular compound produced by strain J31 compared to strain M3-23. This study, was the first showing the antimicrobial efficiency of moderately halophilic bacteria by means of their intracellular compounds, by means of the spore germination reduction and the destroy of mycelial growth of Botrytis cinerea, in vitro. The distinguishable characteristics of their intracellular halotolerant and thermotolerant chitinases make them as good candidates for biotechnological applications.
\end{abstract}

Keywords: Moderately halophilic bacteria; Intracellular enzymes; Chitinase; Antimicrobial activity

\section{Introduction}

Biological control, using microorganisms to repress plant diseases, offers an environmentally friendly strategy to control agricultural phytopathogens. It has been studied for more than 70 years and is becoming a realistic alternative to chemical treatments that are still widely used to control diseases caused by plant pathogens. The emergence of fungicide-resistant strains and deregistration of fungicides may provide non-chemical methods especially biocontrol methods. Moderately halophilic bacteria are a group of halophilic micro-organisms able to grow optimally in media containing a wide range of $\mathrm{NaCl}$ concentrations $(3-15 \% \mathrm{NaCl})$ [1]. They constitute a heterogeneous group of micro-organisms and have been studied for their ecology, physiology, biochemistry and genetics [1]. However their biotechnological possibilities have not been extensively exploited. Furthermore, halophilic bacteria produce a wide range of extracellular salt-tolerant hydrolytic enzymes such as amylases, proteases, nucleases, phosphatases, lipases, DNases, pullulanases and xylanases that have diverse potential usages in different areas such as food technology, feed additives and chemical industries [2,3]. Moreover, extremophilic micro-organisms are adapted to survive in ecological niches such as at high temperature, extremes of $\mathrm{pH}$, high salt concentrations and high pressure. These micro-organisms produce unique biocatalysts that function under extreme conditions comparable to those prevailing in various industrial processes [2].

An important bacterial trait for biological control of plant disease is the production of hydrolytic enzymes which degrade fungal cell walls, especially chitinases and $\beta-1,3$-glucanases, these cell wall degrading enzymes are among the key factors involved in the suppression of pathogenic fungi by biocontrol agents [4]. Our laboratory was the pioneer to take an interest in the study of antifungal enzyme from moderately halophilic bacteria such as Virgibacillus marismortui, Terribacillus halophilus, Salinococcus roseus and Planococcus rifitoensis. Previously, these moderately halophilic bacteria were isolated from shallow salt lakes in Tunisia and selected as strong antagonists of $B$. cinerea the causal agent of grey mold disease on strawberries and tomatoes under the commercial standard conditions applied in Tunisia $[5,6]$. Previous research also reported the characterization of extracellular antifungal enzymes such as chitinase, and protease produced by moderately halophilic bacteria $[7,8]$. From our knowledge, there are no reports focusing on the investigation of intracellular antimicrobial activity produced by halophilic bacteria.

In previous work, we have reported the efficiency of the moderately halophilic strain M3-23 of V. marismortui and stain J31 of T. halophilus, in biological control, and their high production of extracellular antifungal enzymes. In this paper, we firstly aimed to evaluate the antimicrobial ability of intracellular enzymes such as chitinase, glucanase and protease produced by these selected

*Corresponding author: Badiaa Essghaier, Microorganisms and Active Biomolecules Laboratory, Faculty of Sciences of Tunis, University Campus, Tunisia Tel: 0021697692685; Fax: 0021671885480; E-mail: badiaaessghaier@gmail.com

Received: December 07, 2013; Accepted December 29, 2013; Published January 02, 2014

Citation: Essghaier B, Dhieb C, Rebib H, Ayari S, Boudabous ARA, et al. (2014) Antimicrobial Behavior of Intracellular Proteins from Two Moderately Halophilic Bacteria: Strain J31 of Terribacillus halophilus and Strain M3-23 of Virgibacillus marismortui. J Plant Pathol Microb 5: 214. doi:10.4172/2157-7471.1000214

Copyright: (c) 2014 Essghaier B, et al. This is an open-access article distributed under the terms of the Creative Commons Attribution License, which permits unrestricted use, distribution, and reproduction in any medium, provided the original author and source are credited. 
Citation: Essghaier B, Dhieb C, Rebib H, Ayari S, Boudabous ARA, et al. (2014) Antimicrobial Behavior of Intracellular Proteins from Two Moderately Halophilic Bacteria: Strain J31 of Terribacillus halophilus and Strain M3-23 of Virgibacillus marismortui. J Plant Pathol Microb 5: 214. doi:10.4172/2157-7471.1000214

moderately halophilic bacteria and tested in vitro their ability to inhibit spore germination and mycelial growth of Botrytis cinerea.

\section{Material and Methods}

\section{Microorganisms}

Bacterial strain: Two moderately halophilic bacteria strain M3-23 of V. marismortui and strain J31 of T. halophilus were isolated from a Tunisian Sebkha. The morphological, physiological and molecular characteristics of these strains were previously described and their 16S rDNA sequences have been deposited in the GenBank database under the accession number GQ2825501 for strain M3-23 and EU435359 for strain J31 as previously described by us [5].

Pathogen strains: To determine the antimicrobial activity of the intracellular protein from two halophilic bacteria described in this paper; gram-positive pathogen bacterium (Staphylococcus aureus), and a phytopathogenic fungus; Botrytis cinerea, were employed and taken from the culture collection of the laboratory of Microorganisms and Biomolecules Actives, Faculty of Sciences in Tunisia

\section{Effect on tomato stems growth}

Tomato plants (hybrid F1 Maria) used in this study were grown in $25 \mathrm{~cm}$ diameter pots in a plastic house. Two moderately halophilic isolates, Terribacillus halophilus (J31) and Virgibacillus marismortui (M3-23) were used for this study. The bacterial antagonists were grown for $48 \mathrm{~h}$ on TSA (Tryptic Soy Agar, Difco) supplemented with 5\% $\mathrm{NaCl}$. After $48 \mathrm{~h}$, the cells were then scraped from the surface of the Petri dishes and diluted in sterilised saline solution $(1 \% \mathrm{NaCl})$. Bacterial suspensions were adjusted to $10^{8} \mathrm{CFU} / \mathrm{ml}$. Bacterial treatments were applied as spray at 10,20,30 and 40 days. Each treatment had 10 replicate plants. All plants were grown in the greenhouse at about 22 C, 75\% relative humidity. The statistical analysis was made with test of multiple comparisons (Dunnett test). Analysis were performed using logicial XLSTAT, test ANOVA. Data are reported in the text and figures as mean values for all replicated experiments \pm standard error of the mean.

\section{Media composition and Intracellular protein fraction prepa- ration}

The investigation of the antifungal activities production by strain M3-23 of V. marismortui and strain J31 of T. halophilus was carried out in a colloidal chitin medium containing $5 \mathrm{~g} / \mathrm{l}$ tryptone, $5 \mathrm{~g} / \mathrm{l}$ yeast extract, $1 \mathrm{~g} / \mathrm{l} \mathrm{K}_{2} \mathrm{HPO}_{4}$ at $\mathrm{pH} 7$ and $0.1 \%(\mathrm{w} / \mathrm{v})$ colloidal chitin. The incubation was maintained for 3 days at $37^{\circ} \mathrm{C}, 180 \mathrm{rev} / \mathrm{min}$. After incubation, each bacterial culture broth was centrifuged at $9000 \mathrm{rpm}$ for $15 \mathrm{~min}$, pellet were collected and rinsed with $1 \% \mathrm{NaCl}$, centrifuged at $12000 \mathrm{rpm}$ for $15 \mathrm{~min} .800 \mu \mathrm{l}$ of extraction protein buffer TEP $(25 \mathrm{mM}$ Tris- $\mathrm{HCl} \mathrm{pH}$ $7.5,100 \mathrm{mM} \mathrm{KCl}, 5 \%$ glycerol) were added and taken for sonication in ice bath (Am25, pulse 0.5-0.5, time $1 \mathrm{~min}$ ). After a centrifugation at $12000 \mathrm{rpm}$ for $30 \mathrm{~min}$, supernatant containing intracellular protein was obtained and sterilized by filtration through a $0.22 \mu \mathrm{m}$ pore size filter (Life Sciences, PALL, Ann Arbor, MI, Acrodisc $32 \mathrm{~mm}$ syringe filter with $0.2 \mu \mathrm{m}$ Supor membrane) and stored at $-20^{\circ} \mathrm{C}$ until further use.

Chitinase assay: Chitinase was determined according to the method of Gomez Ramirez et al. [9] as previously detailed by Essghaier et al. [5]. The mixture volume per volume $(\mathrm{v} / \mathrm{v})$ of intracellular protein extracted and colloidal chitin suspension (10\%) was incubated for $1 \mathrm{~h}$ at $50^{\circ} \mathrm{C}$. The reaction was stopped by adding $1 \mathrm{ml}$ of $1 \% \mathrm{NaOH}$ and shaking. The product was determined by 3,5-dinitrosalicylic acid assay (DNS) and the absorbance was measured at $535 \mathrm{~nm}$. The chitinase activity was defined as the amount of enzyme required to produce 1 $\mu \mathrm{mol}$ of $\mathrm{N}$-acetylglucosamine (NAG, Sigma) per h per mg of protein [10].

Glucanase assay: The standard assay was performed according to the method of Leelasuphakul et al. [11]. The amount of reducing sugar from Laminarin was measured. The standard assay contained $10 \mu \mathrm{l}$ of the intracellular protein and $90 \mu \mathrm{l}$ Laminarin at $5 \mathrm{mg} / \mathrm{ml}$ in $0.1 \mathrm{M}$ Sodium acetate buffer $\mathrm{pH}$. After incubation at $40^{\circ} \mathrm{C}$ for 10 $\mathrm{min}$, the reaction was stopped by boiling for $5 \mathrm{~min}$ then $0.2 \mathrm{ml}$ of $1 \%$ 3,5-dinitrosalicylic acid (DNS) and $0.2 \mathrm{ml}$ of sodium acetate buffer were added and boiled for another $5 \mathrm{~min}$, then placed in an ice bath; finally $0.9 \mathrm{ml}$ distilled water was added. The optical absorbance was measured at $540 \mathrm{~nm}$. The amount of reducing sugars released was calculated from a standard curve prepared with glucose and the glucanase activity was expressed in units ( $\mu \mathrm{mol}$ glucose equivalent per min).

Protease assay: This was determined by incubating $500 \mu \mathrm{l}$ of $0.5 \%$ Azocasein (sigma) in $0.1 \mathrm{M}$ Tris- $\mathrm{HCl}$ buffer $\mathrm{pH} 8$ with $100 \mu$ of intracellular protein for $1 \mathrm{~h}$ at $37^{\circ} \mathrm{C}$. The reaction was stopped by adding $500 \mu \mathrm{l}$ of $15 \%$ TCA (trichroloroacetic acid) and shaking. This was left for $15 \mathrm{~min}$ and centrifuged at $7000 \mathrm{rpm}$ at $4^{\circ} \mathrm{C}$ for $10 \mathrm{~min} .1 \mathrm{ml}$ of supernatant was added to $1 \mathrm{ml}$ of $1 \mathrm{M} \mathrm{NaOH}$ and absorption was measured at $440 \mathrm{~nm}$. One unit (U) of protease activity was defined as the amount of enzyme that liberated $1 \mu \mathrm{mol}$ of tyrosine per min at $37^{\circ} \mathrm{C}$ [12].

\section{Lysozyme activity}

After culture of Staphylococcus aureus for $48 \mathrm{~h}$ at $30^{\circ} \mathrm{C}$, bacterial cell was centrifuged, twice washed with distilled water, suspended in $50 \mathrm{mM}$ sodium phosphate buffer $\mathrm{pH}$ 6.5. After that, volume per volume (v/v) bacterial suspension and intracellular proteins from each halophilic bacterium were incubated at $37^{\circ} \mathrm{C}$ for $30 \mathrm{~min}$. The optical density was measured at $660 \mathrm{~nm}$. One unit of lysozyme activity was determined as the decrease of OD at $660 \mathrm{~nm}$ with 0.01 per min compared to control tube contained volume (v) pathogen bacteria and volume (v) buffer without the intracellular complex.

\section{Spore germination Inhibition}

B. cinerea was grown at $25^{\circ} \mathrm{C}$ on potato dextrose agar in $9 \mathrm{~cm}$ diameter Petri dishes for 10 to 15 days. Sterile water $(20 \mathrm{ml})$ was added to each plate, and the surface was scraped gently with a sterile loop to release the spores. The resulting spore suspension was filtered through a sterile $30 \mu \mathrm{m}$ filter to remove any mycelial fragments and diluted with sterile water to the desired concentration of about 106 spores $/ \mathrm{ml}$. Conidial suspension of fungus was adjusted to $10^{6}$ spores/ $\mathrm{ml}$ by counting with a haemocytometer. To investigate the effects of the intracellular proteins from both strain M3-23 and J31, on spores germination; $20 \mu \mathrm{l}$ of conidial suspensions adjusted at $10^{6}$ spores $/ \mathrm{ml}$ and $20 \mu \mathrm{l}$ of the intracellular proteins were pipetted into an Eppendorf tube containing $1 \mathrm{ml}$ of sterile distilled water with 5\% glucose, the mix was then incubated at $21^{\circ} \mathrm{C}$ for $24 \mathrm{~h}$. Control tubes were inoculated only with fungal spores. The percentage of spore germination inhibition (I\%) was determined by microscopic examination of spores in the presence of the intracellular proteins from each bacterium (E), compared to control tube containing only the spore suspensions. The percentage of spores germination was determined as; I (\%): (C-E)/C X 100. Three replicates were used for each treatment [13].

\section{Mycelial hyphae destruction}

Fungal culture was rinsed with distilled sterile water. After centrifugation at $9000 \mathrm{rpm}$ for $10 \mathrm{~min}$ pellet (mycelium) was replaced 
Citation: Essghaier B, Dhieb C, Rebib H, Ayari S, Boudabous ARA, et al. (2014) Antimicrobial Behavior of Intracellular Proteins from Two Moderately Halophilic Bacteria: Strain J31 of Terribacillus halophilus and Strain M3-23 of Virgibacillus marismortui. J Plant Pathol Microb 5: 214. doi:10.4172/2157-7471.1000214

in an Eppendorf tube containing an appropriate Tris- $\mathrm{HCl}$ buffer $(0.01 \mathrm{M}, \mathrm{pH} 8)$, in order to obtain the same concentration of mycelial solution (expressed in $\mathrm{mg} / \mathrm{ml}$ ) for each intracellular bacterial fraction tested. A volume of each intracellular fraction was added. The mixture was incubated at $37^{\circ} \mathrm{C}$ for $14 \mathrm{~h}$. After that, optical density was measured at $540 \mathrm{~nm}$. Increase of OD compared to control tube (containing only mycelial suspension), make destruction of fungal hyphae by intracellular fraction.

\section{Intracellular chitinase characterization}

The optimum temperature for intracellular chitinases was determined by monitoring each activity at $\mathrm{pH} 8$ at various temperatures ranging from 40 to $100^{\circ} \mathrm{C}$. The heat stability was analyzed by measuring the residual activity after pre-incubation of the enzymes for $30 \mathrm{~min}$ at various temperatures 40 to $100^{\circ} \mathrm{C}$ [14].

The $\mathrm{pH}$ optimum of the enzymes was determined by applying a substrate solution at different $\mathrm{pH}$ from 4 to 12 and was measured at optimum temperature $\left(90^{\circ} \mathrm{C}\right.$ for strain $\mathrm{M} 3-23$ and $80^{\circ} \mathrm{C}$ for strain $\left.\mathrm{J} 31\right)$. The $\mathrm{pH}$ was adjusted by using the following buffers: $0.1 \mathrm{M}$ phosphate buffer ( $\mathrm{pH} 4.0$ to 6.0 ), $0.1 \mathrm{M}$ Tris- $\mathrm{HCl}$ buffer ( $\mathrm{pH} 7.0$ to 8.0 ), $0.1 \mathrm{M}$ $\mathrm{H}_{3} \mathrm{BO}_{3}-\mathrm{NaOH}$ buffer ( $\mathrm{pH} 9.0$ to 10 ) and $0.1 \mathrm{M} \mathrm{Na}_{2} \mathrm{HPO}_{4}-\mathrm{NaOH}(\mathrm{pH}$ 12). The $\mathrm{pH}$ stability was examined by incubating enzymes in the mentioned buffers for $1 \mathrm{~h}$ at $4^{\circ} \mathrm{C}$ before adding the substrate. The remaining activities (\%) were subsequently determined [15]. The experiments were repeated three times and mean values were taken.

\section{The optimum salinity}

To determine salt optimum for enzymatic activity, each buffer with $\mathrm{pH}$ optimum was added with $\mathrm{NaCl}$ to give a gradient of salt concentration varied from 0 to $30 \% \mathrm{NaCl}(\mathrm{w} / \mathrm{v})$. Enzymatic reactions were maintained at temperatures and $\mathrm{pH}$ optimum for each bacterium $\left(80^{\circ} \mathrm{C}, \mathrm{pH} 4\right.$ for strain $\mathrm{J} 31$ of T. halophilus and $90^{\circ} \mathrm{C}, \mathrm{pH} 12$ for strain M3-23 of V. marismortui).

\section{Results and Discussion}

Previous studies have shown that halophilic bacteria from shallow salt lakes located in Tunisia were successful for pre- and postharvest

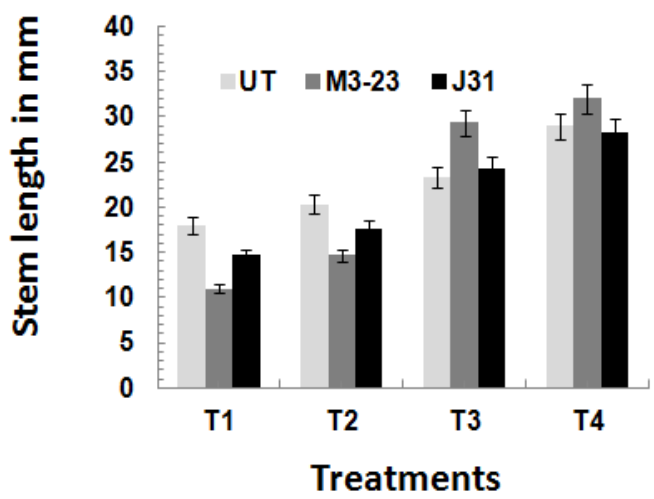

Figure 1A: Effect of biological treatment by means of strain solutions spray on tomato plant growth by measuring stem length, and four repetitions were applied at period of about 10 days.

NB: T1, T2, T3 and T4 mean respectively treatment after 10, 20, 30 and 40 days from the first biological treatment. UT, M3-23 and J31 means respectively untreated plant, biological solution adjusted to $10^{8} \mathrm{CFU} / \mathrm{ml}$ of strain M3-23 and strain J31. Bars indicate standard deviation.
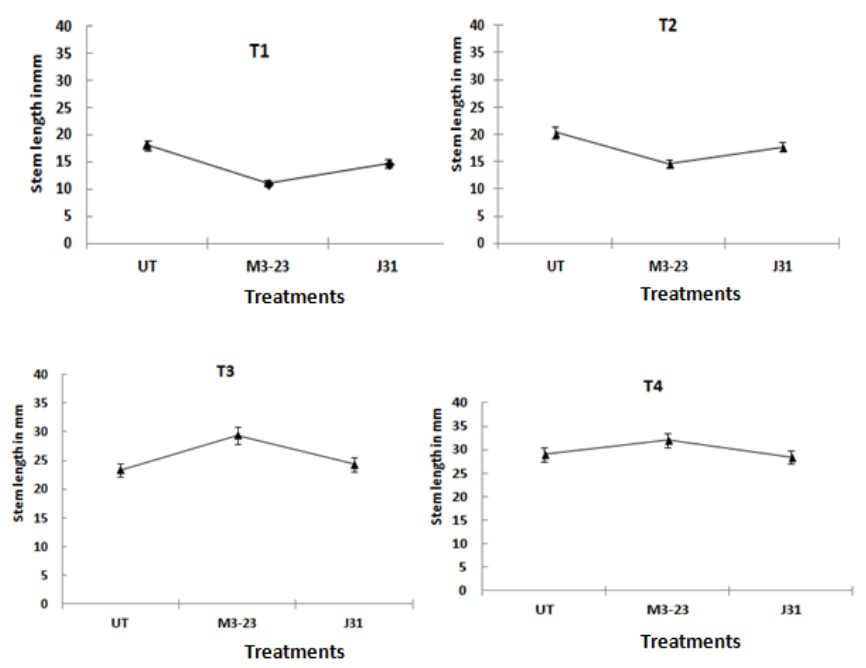

Figure 1B: Analysis of the averages of length differences between the untreated (UT) and the treated plant by biological solutions adjusted to $10^{8} \mathrm{CFU} / \mathrm{ml}$ of strain M3-23 of Virgibacillus marismortui (M3-23) and strain J31 of Terribacillus halophilus (J31) under four treatments (T1, T2, T3 and T4) according to Dunnett test.

NB: T1, T2, T3 and T4 mean respectively treatment after 10, 20, 30 and 40 days from the first biological treatment.

treatments of tomato and strawberry crop in Tunisia $[5,6,16]$. In addition, on one hand, previously, we were the pioneer to evaluate the ability of halophilic bacteria to protect plant diseases from phytopathogenic fungi. On the other hand, these halophilic bacteria were able to produce extracellular antifungal enzymes such as chitinase, glucanase and protease. In earlier work, these extracellular antifungal enzymes exhibited potential properties (tolerance and stability in the presence of extreme conditions $(\mathrm{pH}$, temperature and salt) compared to others published bacterial antifungal enzymes. Therefore, the biotechnological exploitation of these enzymes should be of great importance in agro-industries.

As an extension of our studies, in this work, we extracted the intracellular proteins from two halophilic bacteria and tested them in vitro for their potential antimicrobial properties such as on cell wall degradation, spore germination and mycelial destruction of the phytopathogen (Botrytis cinerea). Previously, we have demonstrated the ability of halophilic bacteria to reduce greymould disease on tomato plant. There are no reports on the use of halophilic bacteria to induce plant growth, so in this work, we are screening two antagonistic halophilic bacteria strain J31 of T. halophilus and strain M3-23 of $V$. marismortui to investigate their effect on growth plant. The results presented in Figure 1A, had shown that both strains used were able to improve stem growth by comparison with control plant (untreated plant) with the most efficiency of strain M3-23 compared to strain J31 specially in treatments T3 and T4 (Figure 1B). The performance of strain M3-23 to improve stem tomato growth was markedly evaluated and confirmed by statistical analysis according to Dunnett test, based on the comparison of the difference between untreated plant and the biological treated (Figure 1B). The highest effect of growth improve have been obtained by strain M3-23 after 30 and 40 days of treatment.

\section{Fungal Cell wall degrading enzymes}

The ability of each halophilic bacterium, to produce antifungal intracellular enzyme was mentioned in Figure 2. The results shown 
Citation: Essghaier B, Dhieb C, Rebib H, Ayari S, Boudabous ARA, et al. (2014) Antimicrobial Behavior of Intracellular Proteins from Two Moderately Halophilic Bacteria: Strain J31 of Terribacillus halophilus and Strain M3-23 of Virgibacillus marismortui. J Plant Pathol Microb 5: 214. doi:10.4172/2157-7471.1000214

Page 4 of 7

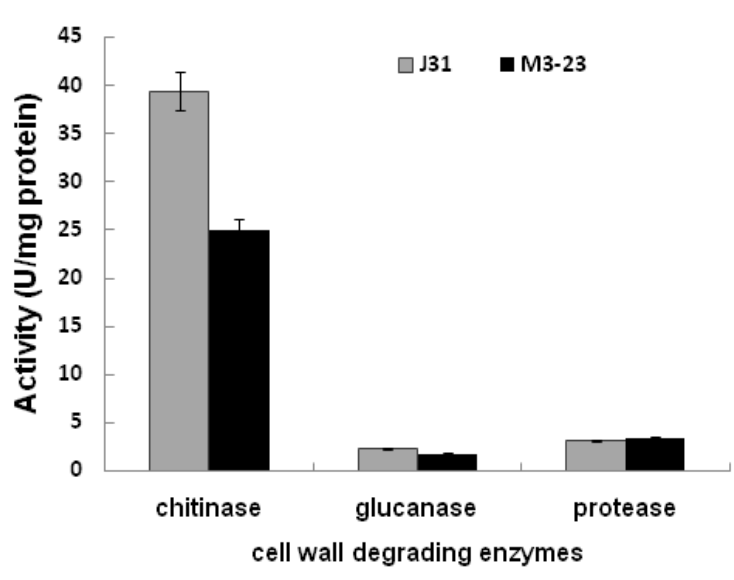

Figure 2: Quantification of cell wall degrading enzymes given in the intracellular proteins extracted from two moderately halophilic bacteria stain M3-23 of Virgibacillus marismortui and strain $\mathrm{J} 31$ of Terribacillus halophilus. Values shown are the average from triplicate experiments. Error bars Standard deviation.

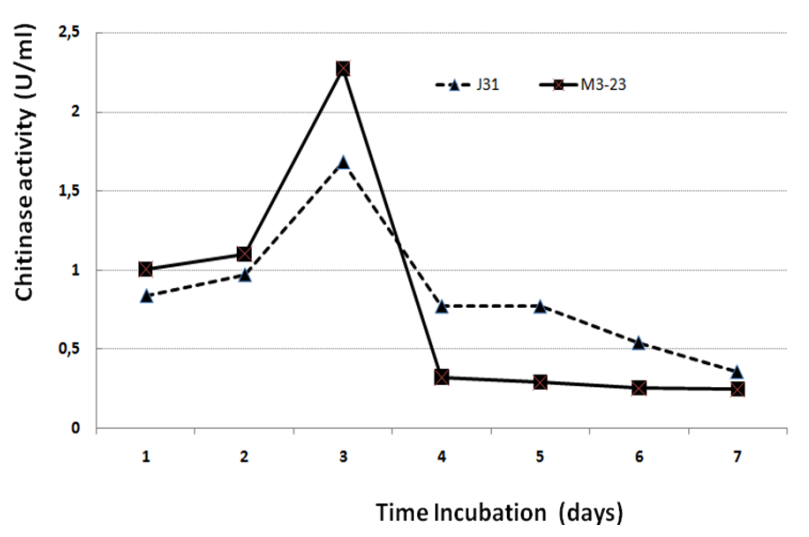

Figure 3: Kinetic production of intracellular chitinases by both moderately halophilic bacteria strain M3-23 of V. marismortui and strain J31 of T. halophilus.

that in the conditions used here, both moderately halophilic bacteria were able to produce intracellular antifungal enzymes: chitinase, glucanase and protease. But the production of intracellular chitinase was highly induced than the production of intracellular glucanase and protease. Since the value of chitinase production range from 39.39U/ $\mathrm{mg}$ of protein for strain $\mathrm{J} 31$ to $24.87 \mathrm{U} / \mathrm{mg}$ of protein for strain M323. But values for others intracellular enzyme production were less than $3.27 \mathrm{U} / \mathrm{mg}$ of protein for intracellular protease from strain M323 and $2.3 \mathrm{U} / \mathrm{mg}$ of protein for intracellular glucanase produced by strain J31. For that reason, we have selected the intracellular chitinases from both strains J31 and M3-23 for biochemical characterization. In consideration of the quantification of enzyme production, the results shown that both moderately halophilic bacteria, were able to produce high intracellular chitinases by comparison with others intracellular antifungal enzymes:Glucanase and Protease. Similar results published by us shown the high extracellular chitinase production by halophilic bacteria compared to extracellular glucanase and protease [5]. Both strains were able to produce a maximum of intracellular chitinases after three days of incubation in medium containing colloidal chitin as sole carbon source (Figure 3).

Chitinase bacterial induction by chitin from crustacean shells in the marine environment has been extensively demonstrated. Bacteria produce chitinase to utilize chitin producing $\mathrm{C}$ and $\mathrm{N}$ sources to meet their nutritional requirements [17]. Some Tunisian sebkha (e.g El Melah), which was the origin of our bacteria were connected to the sea since the sea water pours in the sebkha could take with him by example chitin. So similar chitinase induction from our bacteria isolated from Tunisian sebkha could also be induced by chitin from crustacean shells.

One bacterium usually produces several chitinases probably due to efficient hydrolysis of chitin or hydrolyzes different forms of chitin found in nature $[17,18]$. As chitin is probably the most abundant biopolymer in the marine environment, marine chitinase producing bacteria play quite an important role in chitin degradation. There are many chitinase genes cloned, sequenced and studied from marine bacteria [19].

\section{Intracellular physicochemical chitinase characterization}

Chitin, an insoluble b-1,4-linked polymer of $\mathrm{N}$-acetylglucosamine, is the second most abundant polysaccharide in nature and a major constituent of the cell walls of many fungi, insect exoskeletons, and crustacean shells (eg [20]. Degradation of chitin is essentially catalyzed by chitinases $[21,22]$. Chitinases (E.C. 3.2.1.14) are found in bacteria, fungi, virus, and higher plants. Furthermore, bacterial chitinases are considered primarily to digest and utilize chitin as a carbon and nitrogen nutrient. Several Bacillus species produces enzymes that degrade chitin. Recently, our laboratory showed the production of extracellular chitinase enzymes inducibles by the pathogen in vitro by antimicrobial halotolerant to moderately halophilic bacteria $[5,7,8]$.

Effect of salinity on intracellular chitinases production was presented in Figure 4. The results shown that the intracellular chitinases from both moderately halophilic bacteria, were significantly produced in the absence and at high salt concentration $(30 \% \mathrm{NaCl}(\mathrm{w} / \mathrm{v})$ which clearly indicated the highly salt-tolerant nature of the enzymes. Optimal activity (100\% of original activity) was obtained at $0 \% \mathrm{NaCl}$. By comparison with few studies on halo-tolerance of chitinases, same results of salt tolerant chitinase has been proved with others chitinases produced from halophilic bacteria such as Salinivibrio costicola 5SM1 [23], Planococcus rifitoensis M2-26 [7]. As well as by the marine bacteria Vibrio harveyi and Alteromonas sp. strain O-7 [18,24]. Chitinases with these characteristics may have interesting applications in biotechnological sectors. Especially in biological agricultural process,

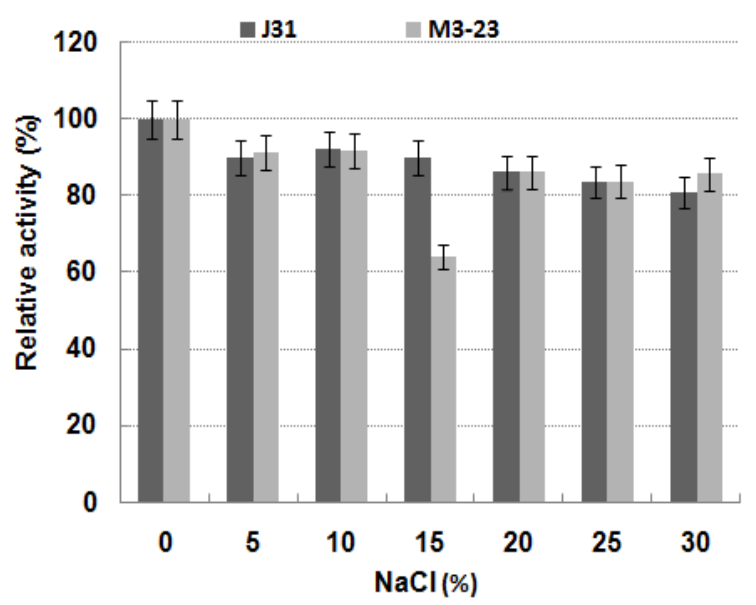

Figure 4: Effects of salt on intracellular chitinases activities of $V$. marismortui strain M3-23 and T. halophilus strain J31. The values shown are percentages of the maximum activity of the enzyme which is taken as $100 \%$. Value is the average from triplicate experiments. Error bars represent the standard deviation. 
Citation: Essghaier B, Dhieb C, Rebib H, Ayari S, Boudabous ARA, et al. (2014) Antimicrobial Behavior of Intracellular Proteins from Two Moderately Halophilic Bacteria: Strain J31 of Terribacillus halophilus and Strain M3-23 of Virgibacillus marismortui. J Plant Pathol Microb 5: 214. doi:10.4172/2157-7471.1000214
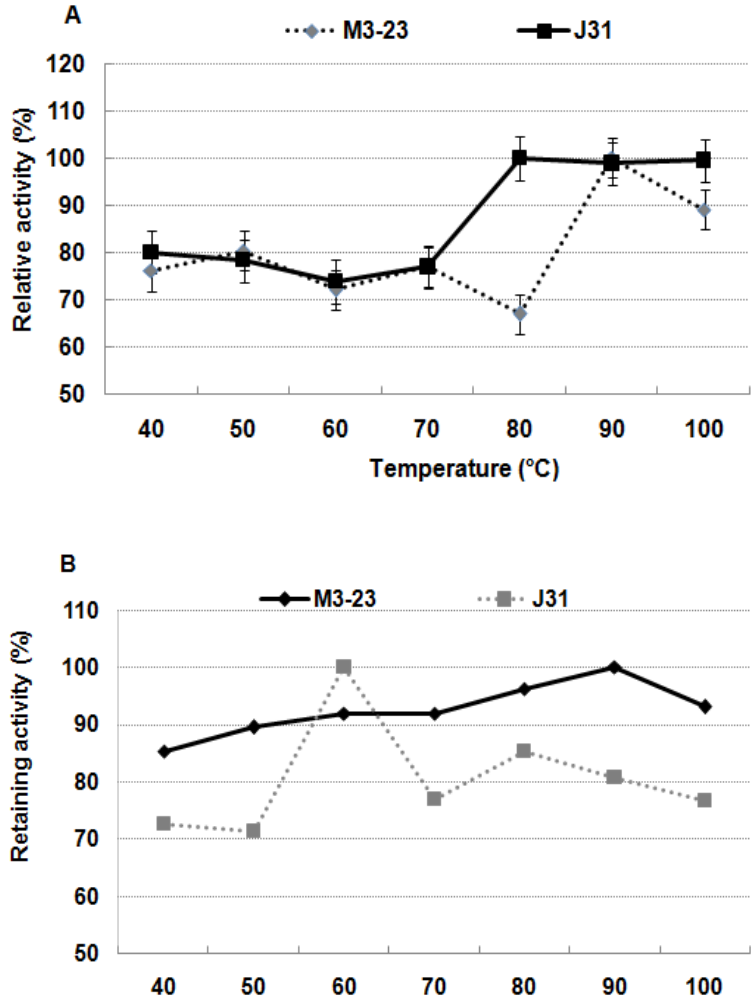

Figure 5: Effects of temperature on intracellular chitinases activity $(A)$ and stability (B) of $V$. marismortui strain M3-23 and T. halophilus strain J31. The values shown are percentages of the maximum activity of the enzyme which is taken as $100 \%$. Value is the average from triplicate experiments. Error bars represent the standard deviation.

applied in saline soil such almost Tunisian soil due to the expansive use of a heavy dressing of manure and the irrigation with brackish waters characterized by the presence of high $\mathrm{NaCl}$ concentrations of about 3 to $4 \mathrm{~g} / \mathrm{l}[25]$.

The effect of temperature on the activity and stability of the intracellular chitinases is presented in Figure 5. Maximal chitinase activities was found respectively at $90^{\circ} \mathrm{C}$ and at $80^{\circ} \mathrm{C}$ for strain $\mathrm{M} 3-$ 23 and strain J31. However, the results of thermostability showed that intracellular chitinases from strain M3-23 was more stable over a broad range of temperatures between 40 and $100^{\circ} \mathrm{C}$ retaining $85.27 \%$ of its activity compared to only $71.75 \%$ for chitinase stability from strain J31. Although a large number of chitin hydrolyzing enzymes have been isolated, only a few thermostable chitin-hydrolyzing enzymes are known to be active at above $70^{\circ} \mathrm{C}$ [2]. The optimum temperature of thermostable chitinases from $B$. stearothermophilus $\mathrm{CH}-4 \quad\left(75^{\circ} \mathrm{C}\right)$ [26]. Streptomyces thermoviolaceus OPC-520 (70$80^{\circ} \mathrm{C}$ ) [27], and Planococcus rifitoensis [7]. These characteristics of thermo-tolerant and halotolerant enzyme are of great importance in metabolic production, and for the biocontrol ability against fungi and for protecting plants under biocontrol saline conditions as well as in future applications of these enzymes in any biotechnological process that depends on high salinity or osmotic pressure for long incubation periods [28].

The effect of $\mathrm{pH}$ on the activity and stability of the chitinase are illustrated in Figure 6 which shows that the intracellular chitinase from strain M3-23 of $V$. marismortui at $90^{\circ} \mathrm{C}$, has the highest activity at $\mathrm{pH}$
12.0 and was active over a broad $\mathrm{pH}$ range between 4 and 12, retaining greater than $90 \%$ of its original activity. Strain M3-23 produces an alkaline chitinase; similar observations were reported for Alcaligenes xylosoxydans ( $\mathrm{pH}$ 8.0) [29], Streptomyces thermoviolaceus OPC-520 (pH 8.0-10) [27] and Planococcus rifitoensis ( $\mathrm{pH}$ 8.0) [7], Bacillus atrophaeus SC081 (pH8) [30]. The effects of pH on the activity and stability of J31 intracellular chitinase was examined at optimum temperature $80^{\circ} \mathrm{C}$. Maximum activity was observed at $\mathrm{pH}$ 4.0. The enzyme was active and retained greater than $90 \%$ of its activity within a $\mathrm{pH}$ range of 4.0 to 12.0. Unlike the alcaline intracellular chitinase from strain M3-23, an enzyme from strain J31 was acidic. Few reports showed acidic chitinase from bacteria such as chitinase (ChiA) from Bacillus licheniformis [31].

\section{Antimicrobial potentiality of intracellular compounds}

Botrytis cinerea is the causal agent of grey mold disease on a variety of fruits, vegetables, and field crops. In this report we describe novel assays for inhibition of spore germination and growth hyphae in $B$. cinerea, which are based on the use of the intracellular proteins from halophilic bacteria. For investigation of the antimicrobial behavior of intracellular proteins produced by both strain J31 and M3-23, we have tested the ability of lysozyme activity, spores germination inhibition and mycelial destruction of $B$. cinerea. The results of lysozyme activity produced by intracellular proteins have demonstrated that both bacteria
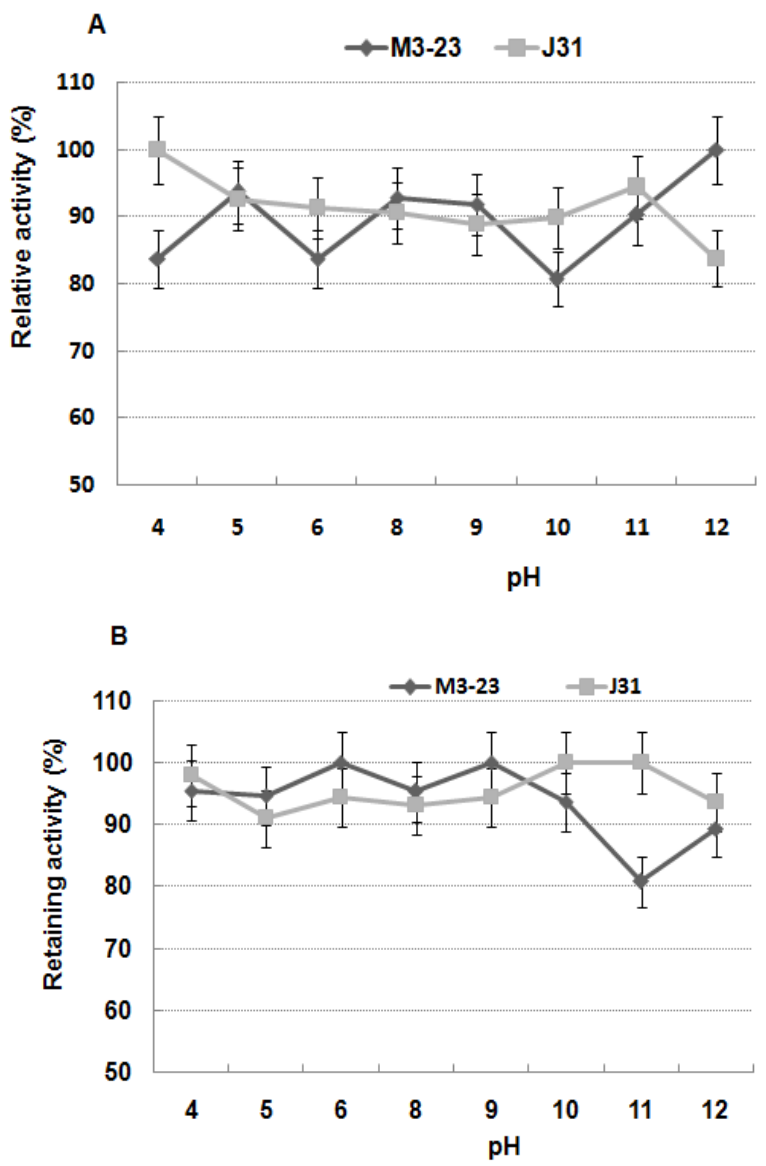

Figure 6: Effects of $\mathrm{pH}$ value on intracellular chitinase activity $(\mathrm{A})$ and stability (B) of $V$. marismortui strain M3-23 and T. halophilus strain J31. The values shown are percentages of the maximum activity of the enzyme which is taken as $100 \%$. Value is the average from triplicate experiments. Error bars represent the standard deviation. 
Citation: Essghaier B, Dhieb C, Rebib H, Ayari S, Boudabous ARA, et al. (2014) Antimicrobial Behavior of Intracellular Proteins from Two Moderately Halophilic Bacteria: Strain J31 of Terribacillus halophilus and Strain M3-23 of Virgibacillus marismortui. J Plant Pathol Microb 5: 214. doi:10.4172/2157-7471.1000214

Page 6 of 7

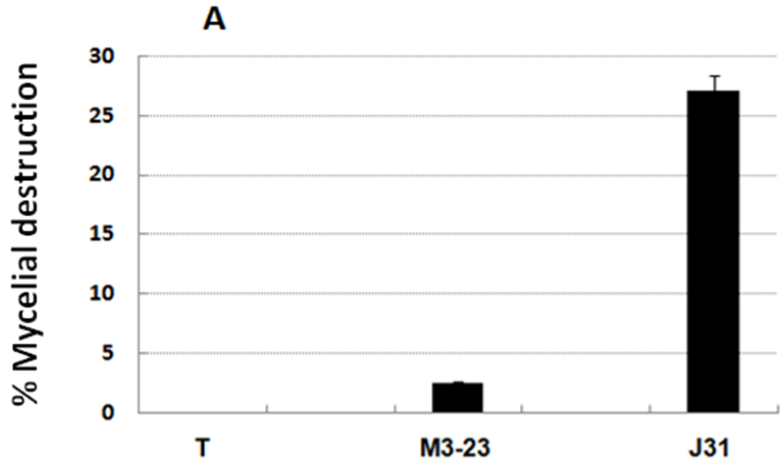

Treatments

B

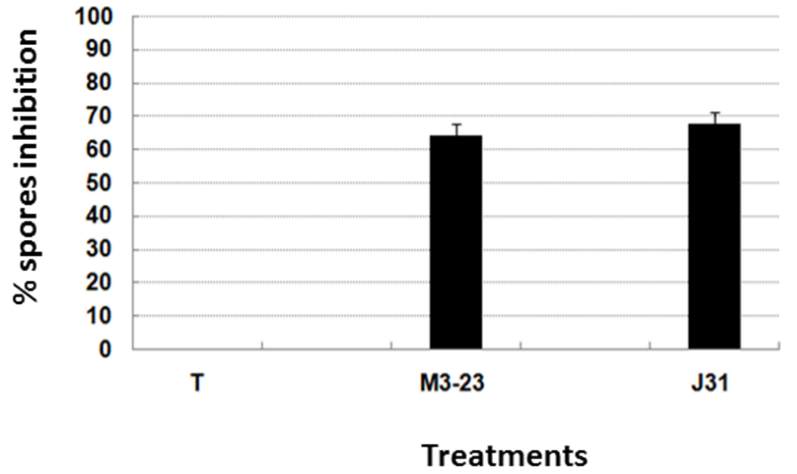

Figure 7: Effects of intracellular proteins produced by $V$. marismortui strain M3-23 and T. halophilus strain J31, on mycelium destruction (A) and spores germination inhibition (B) of Botrytis cinerea, under conditions tested. Value is the average from triplicate experiments. Error bars represent the standard deviation.

have lysozyme activity presented in their intracellular protein fraction with respectively $6.6 \mathrm{U} / \mathrm{ml}$ and $6.8 \mathrm{U} / \mathrm{ml}$ for strain $\mathrm{J} 31$ of $T$. halophilus and strain M3-23 of $\mathrm{V}$. marismortui. It is worth pinpointing that, the combination of lysozyme activity to antifungal enzymes (chitinase, protease and glucanase) were rare and offer great potential use of such antimicrobial compounds in biotechnological area for example to assure food safety and consumer health by producing good quality wines [32].

The intracellular fraction produced by each bacterium was able to destroy mycelium of $B$. cinerea (Figure 7A) and to inhibit its spore germination (Figure $7 \mathrm{~B}$ ). On the whole, the most potent in vitro antifungal effect was demonstrated by intracellular compound produced by a strain J31 of T. halophilus with respectively $67.58 \%$ compared to $64.25 \%$ spores inhibition given by strain M3-23 of V. marismortui. As regards only the intracellular proteins produced by strain J31 of T. halophilus have a strong effect on the mycelial destruction with $27 \%$ compared to only $2.55 \%$ for strain M3-23 of V. marismortui. Numerous studies have demonstrated the ability of bacteria to inhibit spore germination, but this work was the first addresses the ability of halophilic bacteria to produce intracellular proteins inhibiting spore germination and mycelial growth of fungus (Figures 7A and 7B).

Recently, in the course of our research on the biologically active compound, in this work, we investigated the efficiency of intracellular enzymes from halophilic bacteria to inhibit $B$. cinerea agent causal of grey-mould disease in number crop. Nowadays, consumers are aware of the health concerns regarding food additives; the health benefits of "natural" and "traditional" foods, processed without any addition of chemical preservatives, are becoming more attractive. Thus, because of recent consumer demand for higher quality and biodegradable bioactive compound, researchers all over the world are looking for new bioactive metabolites. In previous work, we have been reporting on the efficiency of halophilic bacteria in agriculture as a biological agent. Furthermore, in this study, we have mentioned the ability of the moderately halophilic bacteria to produce not only intracellular antimicrobial compounds but also stable at extreme conditions (salt, $\mathrm{pH}$ and temperature). Characterization of biochemical properties suggested that the intracellular chitinases were salt thermo and $\mathrm{pH}$ stable, suitable for various biotechnological applications, including bioconversion of colloidal chitin and chitobiose into NAG or the juice industry.

\section{Acknowledgments}

This work was supported by funds from the Ministry of Higher Education and Scientific Research (Tunisia).

\section{References}

1. Ventosa A, Nieto JJ, Oren A (1998) Biology of moderately halophilic aerobic bacteria. Microbiol Mol Biol Rev 62: 504-544.

2. Niehaus F, Bertoldo C, Kähler M, Antranikian G (1999) Extremophiles as a source of novel enzymes for industrial application. Appl Microbiol Biotechnol 51: 711-729.

3. Pandey A, Soccol CR, Mitchell DA (2000) New developments in solid-state fermentation I-bioprocesses and products. Proc Biochem 1153-1169.

4. Ordentlich A, Elad Y, Chet I (1988) The role of chitinase of Serratia marcescens in biocontrol of Sclerotium rolfsii. Phytopathol 78: 84-88.

5. Essghaier B, Fardeau ML, Cayol JL, Hajlaoui MR, Boudabous A, et al. (2009) Biological control of grey mould in strawberry fruits by halophilic bacteria. J Appl Microbiol 106: 833-846.

6. Sadfi-Zouaoui N, Essghaier B, Hajlaoui MR, Fardeau ML, Cayol JL, et al. (2008) Ability of moderately halophilic bacteria to control grey mould disease on tomato fruits. J Phytopathol 156: 42-52.

7. Essghaier B, Rouaissi M, Boudabous A, Jijakli H, Sadfi-Zouaoui N (2010) Production and partial characterization of chitinase from a halotolerant Planococcus rifitoensis strain M2-26. World J Microbiol Biotechnol 26: 977-984.

8. Essghaier B, Hedi A, Bejji M, Jijakli H, Boudabous A, et al. (2012) Characterization of a novel chitinase from a moderately halophilic bacterium Virgibacillus marismortui strain M3-23. Ann Microbiol 62: 835-841.

9. Gomez Ramirez M, Rojas Avelizapa LI, Rojas Avelizapa NG, Cruz Camarillo R (2004) Colloidal chitin stained with Remazol Brillant Blue R, a useful substrate to select chitinolytic microorganisms and to evaluate chitinases. J Microbiol Methods 56: 213-219.

10. Roja Avelizapa LI, Cruz Camarillo R, Guerro MI, Rodriguez Vazquez R Ibarra JE (1999) Selection and characterization of a proteo-chitinolytic strain of Bacillus thuringiensis, able to grow in shrimp waste media. World J Microb Biotech15: 299-308.

11. Leelasuphakul W, Sivanunsakul P, Phongpaichit S (2006) Purification, characterization and synergistic activity of $\beta-1-3-$ glucanase and antibiotic extract from an antagonistic Bacillus subtilis NSRS89-24 against rice blast and sheath blight. Enzyme Microbiol Tech 38: 990-997.

12. Olajuyigbe FM, Ajele JO (2005) Production dynamics of extracellular protease from Bacillus species. Afr J Biotech 4: 776-779.

13. Sarangi N, Athukorala P, Dilantha Fernando WG, Rashid KY, Kievit TD (2010) The role of volatile and non-volatile antibiotics produced by Pseudomonas chlororaphis strain PA23 in its root colonization and control of Sclerotinia sclerotiorum. Biocontrol Sci Technol 20: 875-890.

14. Issam SM, Mohamed G, Farid L, Sami F, Thierry M, et al. (2003) Production, purification, and biochemical characterization of two beta-glucosidases from Sclerotinia sclerotiorum. Appl Biochem Biotechnol 111: 29-40. 
Citation: Essghaier B, Dhieb C, Rebib H, Ayari S, Boudabous ARA, et al. (2014) Antimicrobial Behavior of Intracellular Proteins from Two Moderately Halophilic Bacteria: Strain J31 of Terribacillus halophilus and Strain M3-23 of Virgibacillus marismortui. J Plant Pathol Microb 5: 214. doi:10.4172/2157-7471.1000214

15. Ellouze O, Mejri M, Smaali I, Limam F, Marzouki MN (2007) Induction, properties and application of xylmanase activity from Slerotinia sclerotiorum S2 Fungus. J Food Biochem 31: 96-107.

16. Sadfi-Zouaoui N, Hannachi I, Andurand D, Essghaier B, Boudabous A, et al. (2008) Biological control of Botrytis cinerea on stem wounds with moderately halophilic bacteria. World J Microbiol Biotech 24: 2871-2877.

17. Clarke PH, Tracey MV (1956) The occurrence of chitinase in some bacteria. J Gen Microbiol 14: 188-196.

18. Svitil AL, Chadhain S, Moore JA, Kirchman DL (1997) Chitin Degradation Proteins Produced by the Marine Bacterium Vibrio harveyi Growing on Different Forms of Chitin. Appl Environ Microbiol 63: 408-413.

19. Suginta W, Robertson PA, Austin B, Fry SC, Fothergill-Gilmore LA (2000) Chitinases from Vibrio: activity screening and purification of chiA from Vibrio carchariae. J Appl Microbiol 89: 76-84.

20. Felse PA, Panda T (1999) Regulation and cloning of microbial chitinase genes. Appl Microbiol Biotechnol 51: 141-151.

21. Flach J, Pilet PE, Jollès $P$ (1992) What's new in chitinase research? Experientia 48: 701-716.

22. Cohen-Kupiec R, Chet I (1998) The molecular biology of chitin digestion. Curr Opin Biotechnol 9: 270-277.

23. Aunpad R, Panbangred W (2003) Cloning and characterization of the constitutively expressed chitinase $\mathrm{C}$ gene from a marine bacterium, Salinivibrio costicola strain 5SM-1. J Biosci Bioeng 96: 529-536.

24. Tsujibo H, Kondo N, Tanaka K, Miyamoto K, Baba N, et al. (1999) Molecular analysis of the gene encoding a novel transglycosylative enzyme from
Alteromonas sp. strain 0-7 and its physiological role in the chitinolytic system. J Bacteriol 181: 5461-5466.

25. Messaï A, Hannachi C, Zid E (2006) In vitro Regeneration of NaCl-adapted Tomato Plants (Lycopersicon esculentum Mill.) Tropicultura 24: 221-228.

26. Sakai K, Narihara M, Kasama Y, Wakayama M, Moriguchi M (1994) Purification and characterization of thermostable beta- $\mathrm{N}$-acetylhexosaminidase of Bacillus stearothermophilus $\mathrm{CH}-4$ isolated from chitin-containing compost. Appl Environ Microbiol 60: 2911-2915.

27. Tsujibo H, Minoura K, Miyamoto K, Endo H, Moriwaki M, et al. (1993) Purification and properties of a thermostable chitinase from Streptomyces thermoviolaceus OPC-520. Appl Environ Microbiol 59: 620-622.

28. Margesin R, Schinner F (2001) Potential of halotolerant and halophilic microorganisms for biotechnology. Extremophiles 5: 73-83.

29. Vaidya RJ, Shah IM, Vyas PR, Chhatpar HS (2001) Production of chitinase and optimization from a novel isolate Alcaligenes xylosoxydans: potential in antifungal biocontrol. World J Microbiol Biotech 17: 691-696.

30. Cho EK, Choi IS, Choi YJ (2011) Overexpression and characterization of thermostable chitinase from Bacillus atrophaeus SC081 in Escherichia coli. BMB Rep 44: 193-198.

31. Songsiriritthigul C, Lapboonrueng S, Pechsrichuang P, Pesatcha $P$, Yamabha $M(2010)$ Expression and characterization of Bacillus licheniformis chitinase (ChiA), suitable for bioconversion of chitin waste. Bioresour Technol 101: 40964103.

32. Visan L, Margarit G, Groposila D,Varga M (2009) Lysosyme enzymatic activity changes in control of malolactic fermentation used in Romanian wines. Lucrăr Ştiintifice 438-444. 